\title{
Intractable diarrhea of infancy
}

INSERM

\section{Source}

INSERM. (1999). Orphanet: an online rare disease and orphan drug data base. Intractable diarrhea of infancy. ORPHA:73014

Intractable diarrhoea of infancy (IDI) is a heterogeneous syndrome that includes several diseases with different aetiologies. Provisional classification of IDI, according to villous atrophy and based on immunohistological criteria, distinguishes two clearly different groups of IDI: 1) Immune-mediated: characterised by a mononuclear cell infiltration of the lamina propria and considered as being related to T cell activation. 2) The second histological pattern includes early onset severe intractable diarrhoea histologically characterised by villous atrophy with low or without mononuclear cell infiltration of the lamina propria but specific histological abnormalities involving the epithelium. 